Soegianto, 2003 Tanggung Jawab Pendiri dan Notaris dalam Kaitannya Dengan Penyetoran Modal Untuk Pembuatan Akta Pendirian Perseroan, Tesis: Universitas Diponegoro Semarang.

III PERUNDANG - UNDANGAN

- Undang-Undang Dasar Negara Republik Indonesia Tahun 1945;

- Kitab Undang-Undang Hukum Perdata;

- Undang-Undang No 30 Tahun 2004 tentang Jabatan Notaris. Lembaran Negara Republik Indonesia Tahun 2004 Nomor 117.

- Undang-Undang No 2 Tahun 2014 tentang perubahan atas Undang-Undang Nomor 30 Tahun 2004 Tentang Jabatan Notaris. Lembaran Negara Republik Indonesia Tahun 2014 Nomor 3.

- Undang-Undang No 12 Tahun 2012 tentang Pembentukan Peraturan Perundangundangan. Lembaran Negara Republik Indonesia Tahun 2011 Nomor 82.

- Peraturan Menteri Nomor M.02.PR.08.10 Tahun 2004 Tentang Tata Cara Pengangkatan Anggota, Pemberhentian Anggota, Susunan Organisasi, Tata Kerja, Dan Tata Cara Pemeriksaan Majelis Pengawas Notaris.

- Peraturan Menteri Nomor M.HH-06.AH.02.10 Tahun 2009 tentang Sekretariat Majelis Pengawas Notaris.

\section{DAFTAR INFORMAN}

1. Nama

Tempat Tanggal Lahir

Umur

Pekerjaan

Alamat
: Josep Sunar Wibisono. SH.

: Mojo Agung, 19 Juli 1946

: 67 Tahun

: Notaris/PPAT di Kota Denpasar

: Jln. Tukad Yeh Ayung No. 35

$* * * * *$

\title{
PERLINDUNGAN HUKUM TERHADAP JABATAN NOTARIS BERKAITAN DENGAN ADANYA DUGAAN MALPRAKTEK DALAM PROSES PEMBUATAN AKTA OTENTIK
}

\author{
Oleh : \\ I Gusti Agung Oka Diatmika* \\ NIM 1292461015 \\ Program Magister Kenotariatan Universitas Udayana \\ e-mail : okadiatmika99@gmail.com \\ Pembimbing I : Prof. Dr. I Dewa Gde Atmadja. SH.,MS.** \\ Pembimbing II : Dr. Ni Ketut Sri Utari, SH.,MH.***
}

\begin{abstract}
THE LEGAL PROTECTION ON THE NOTARY POSITION RELATED TO THE ALLEGED MALPRACTICE IN THE PROCESS OF MAKING AUTHENTIC DEEDS
\end{abstract}

A notary is a public officer who given sufficient authority by the state to make an authentic deed. If a party feels aggrieved over the deed of a Notary, then the party can sue the notary with the charges of malpractice in an authentic deed, although the notary has been working in accordance with the standards of an authentic deed. On this basis, it is need a legal protection for the notary, in this case, made by the Notary Honorary Council (MKN) as provided for in the Article 66 of paragraph (1) of Law No. 2 of 2014 on the Amendment of Law Number 30 of Year 2004 on the Notary Position (UUJN-P). There are no certain regulations on $M K N$ positions and the kinds of legal protection given by the MKN to the notary, giving rise to legal issues namely, what the standards or requirements in the process of making an authentic deed and what the legal protection of the Position of Notary in relations to the allegations of malpractice in the making of authentic deeds.

This thesis research is a normative legal research, which departed from the vacuum of norm. The legal materials collection techniques used were the study of literature and the card system. The analysis of the legal materials was conducted by 
using descriptive techniques, interpretations and arguments associated with the theories and concepts of law which relevant to the issues.

The research findings of the problem under study, namely, that in making authentic deeds, notary must always pay attention to the validity of the agreement according to the terms of Article 1320 of the Civil Law (the Civil Codes), the requirement of making authentic deeds (Civil Code of 1868), Law on the Notary Position, as well as the Notary Code of Ethics. While MKN position as the Administrative agencies should be established in the regions of (city or regencies) in order that MKN can quickly respond to the case and provide an appeal to the parties who are not satisfied with the decision of $M K N$.

Keywords : Legal Protection, Notary, Alleged Malpractice, Authentic Deed

* Mahasiswa Program Studi Magister Kenotariatan T.A 2012/2013

**Pembimbing I

*** Pembimbing II

\section{PENDAHULUAN}

\subsection{Latar Belakang Masalah}

Notaris merupakan pejabat umum yang diberikan kewenangan oleh Negara dalam membuat akta otentik. Kewenangan Notaris diatur dalam Pasal 15 Undang-Undang Nomor 2 Tahun 2014 Tentang Perubahan Atas Undang-Undang Nomor 30 Tahun 2004 Tentang Jabatan Notaris (UUJN-P) yang menyangkut segala bentuk perbuatan, perjanjian, dan ketetapan yang diharuskan oleh peraturan perundang-undangan dan/atau yang dikehendaki oleh pihak yang berkepentingan untuk dinyatakan dalam akta otentik.. Pada hakekatnya akta otentik merupakan kebenaran formil mengenai apa yang diberitahukan para pihak kepada Notaris untuk dimuat dalam akta. Akan tetapi, tidak semua keterangan yang diberikan oleh penghadap atau para pihak kepada notaris itu adalah benar. Penghadap dapat saja memanfaatkan kelengahan Notaris dengan memberikan keterangan atau dokumen palsu kepada Notaris, maka dalam hal ini, akta yang dihasilkan oleh Notaris menjadi tidak benar, sehingga dapat menimbulkan kerugian kepada salah satu pihak. Apabila salah satu pihak merasa dirugikan terhadap akta otentik tersebut, maka notaris dapat dituntut telah melakukan malpraktek, walaupun Notaris tersebut telah bekerja sesuai dengan standar profesinya dalam pembuatan akta otentik. Hal inilah yang menjadi dasar diperlukannya suatu perlindungan hukum bagi jabatan Notaris.

Perlindungan hukum terhadap jabatan notaris telah diatur dalam Pasal 66 ayat (1) UUJN-P yang mengatur tentang lembaga Majelis Kehormatan Notaris (MKN) sebagai lembaga perlindungan hukum bagi notaris. Kewenangan dari MKN ini adalah dalam memberikan persetujuan atau menolak permintaan dari penyidik, jaksa, maupun hakim yang hendak memanggil dan memeriksa Notaris dalam persidangan. Kewenangan ini sebelumnya merupakan kewenangan dari Majelis Pengawas Daerah (MPD), yang kini telah dinyatakan tidak berlaku lagi berdasarkan
Putusan Mahkamah Konstitusi Nomor 49/PUU$\mathrm{X} / 2012$.

Mengenai pengaturan tentang kedudukan serta bentuk perlindungan hukum yang diberikan oleh MKN kepada Notaris belum jelas diatur dalam peraturan perundangudangan. Hal ini menimbulkan kekaburan norma dalam penegakan hukum terhadap jabatan notaris terkait dengan adanya dugaan malpraktek yang dilakukan oleh Notaris dalam proses pembuatan akta otentik.

Berdasarkan uraian diatas, menarik kiranya untuk diangkat suatu permasalahan mengenai perlindungan hukum terhadap Notaris berkaitan dengan adanya dugaan Malpraktek yang dilakukan oleh Notaris dalam membuat akta otentik ke dalam suatu bentuk penelitian dengan judul: "Perlindungan Hukum Terhadap Jabatan Notaris Berkaitan Dengan Adanya Dugaan Malpraktek Dalam Proses Pembuatan Akta Otentik"

\subsection{Rumusan Masalah}

1.2.1 Apakah standar atau syarat bagi seorang Notaris dalam melaksanakan jabatannya dalam pembuatan akta yang bersifat notariil?

1.2.2 Bagaimanakah perlindungan hukum terhadap jabatan Notaris melalui Majelis Kehormatan Notaris (MKN) terkait dengan adanya dugaan malpraktek yang dilakukan oleh Notaris dalam pembuatan akta otentik ?

\subsection{Landasan Teori}

\subsubsection{Teori Kewenangan}

Jabatan Notaris merupakan jabatan yang lahir atas dasar aturan hukum dan terikat dengan hukum perdata yang memberikan kewenangan membuat akta otentik untuk melayani masyarakat. Kewenangan notaris dalam hal menjalankan tugas jabatannya sebagai pejabat umum merupakan kewenangan yang diperoleh secara atribusi yang secara normatif diatur di dalam UUJN-P. Menurut konsep teori kewenangan menurut Philipus M. Hadjon bahwa: "Setiap tindakan pemerintahan 
disyaratkan harus bertumpu atas kewenangan yang sah. Kewenangan itu diperoleh melalui tiga sumber, yaitu atribusi, delegasi, dan mandat. Kewenangan atribusi lazimnya digariskan melalui pembagian kekuasaan negara oleh undang-undang, kewenangan delegasi adalah kewenangan yang berasal dari adanya "pelimpahan" kewenangan secara atributif sedangkan mandat tidak terjadi suatu "pelimpahan" kewenangan.

\subsubsection{Teori Pertanggungjawaban Hukum}

Secara umum pertanggung jawaban hukum dapat diartikan sebagai keadaan wajib menanggung, memikul tanggung jawab, menanggung segala sesuatunya, (jika ada sesuatu hal, dapat dituntut, dipersalahkan, diperkarakan dan sebagainya) sesuai dengan peraturan hukum yang berlaku. Tanggung jawab hukum adalah kesadaran manusia akan tingkah laku atau perbuatan yang disengaja maupun yang tidak disengaja. ${ }^{2}$

Menurut pendapat Hans Kelsen tentang teori tanggung jawab hukum yang menyatakan bahwa:

a concept related to that of legal duty is the concept of legal responsibility (liability). That a person is legally responsible for a certain behavior or that he bears the legal responsibility therefore means that he is liable to a sanction in case contrary behavior. Normally, that is, in case the sanction is directed againts the immediate delinquent, it is his own behavior for which an individual is responsible. In this case the subject of the legal responsibility and the subject of the legal duty coincide. ${ }^{3}$

Bahwa suatu konsep yang terkait dengan kewajiban hukum adalah konsep tanggung jawab hukum (liability). Seseorang dikatakan secara hukum bertanggungjawab untuk suatu perbuatan tertentu adalah bahwa dia dapat dikenakan suatu sanksi dalam kasus perbuatan berlawanan dengan hukum. Biasanya, dalam kasus, sanksi dikenakan terhadap delinquent (penjahat) karena perbuatannya sendiri yang membuat orang tersebut harus bertanggungjawab. Dalam kasus ini subjek tanggung jawab hukum (responsibility) dan subjek kewajiban hukum adalah sama.

${ }^{1}$ Philipus M. Hadjon, 1997, Penataan Hukum Administrasi, Tentang Wewenang, Fakultas Hukum Unair, Surabaya, (selanjutnya disebut Philipus M. Hadjon I) hal. 2.

${ }^{2}$ Purbacaraka, 2010 , Kaedah Hukum, Citra Aditya, Bandung, hal. 37.

${ }^{3}$ Hans Kelsen, 1944, General Theory Of Law And State, New York. hal. 65.
Terdapat dua macam bentuk pertanggungjawaban, yaitu pertanggungjawaban mutlak (absolut responsibility) dan pertanggungjawaban berdasarkan kesalahan (based on fault)

a) Pertanggungjawaban mutlak (absolut responsibility), yaitu sesuatu perbuatan menimbulkan akibat yang dianggap merugikan oleh pembuat undang-undang dan ada suatu hubungan antara perbuatannya dengan akibatnya. Tiada hubungan antara keadaan jiwa si pelaku dengan akibat dari perbuatannya.

b) Pertanggungjawaban berdasarkan kesalahan (based on fault), atau dikenal juga dalam bentuk lain dari kesalahan yaitu kesalahan yang dilakukan tanpa maksud atau perencanaan, yaitu kealpaan atau kekhilafan (negligance). ${ }^{4}$

1.3.3 Teori Perlindungan Hukum

Perlindungan hukum merupakan suatu perlindungan yang diberikan terhadap subyek hukum dalam bentuk perangkat hukum baik yang bersifat preventif maupun yang bersifat represif, baik yang tertulis maupun tidak tertulis. ${ }^{5}$ Perlindungan hukum merupakan suatu gambaran dari fungsi hukum, yaitu bahwa hukum dapat memberikan suatu keadilan, ketertiban, kepastian, kemanfaatan dan kedamaian.

Menurut pendapat J.B.J.M Ten Berge, berkaitan dengan penggunaan kewenangan ada tiga bentuk perlindungan hukum pada masyarakat, yaitu : ${ }^{6}$

a) bescherming via de democratie (perlindungan hukum melalui demokrasi)

b) bescherming via bestuurlijkhierarchische verhoudingen (perlindungan hukum melalui hubungan administratif-hierarkis)

c) bescherming via juridische voorzieningeni (perlindungan hukum melalui ketentuan hukum)

Notaris sebagai pejabat umum dalam menjalankan jabatannya perlu diberikan perlindungan hukum terkait dengan adanya malpraktek dalam proses pembuatan akta

${ }^{4}$ Jimly Asshiddiqie dan M. Ali Safa'at, 2006, Teori Hans Kelsen Tentang Hukum, Sekretariat Jendral \& Kepaniteraan Mahkamah Konstitusi Republik Indonesia, Jakarta, hal.61.

${ }^{5}$ Phillipus M. Hadjon, 1987, Perlindungan Hukum Bagi Rakyat Indonesia, PT. Bina Ilmu, Surabaya, (selanjutnya disebut Philipus M. Hadjon II) hal. 2.

${ }^{6}$ J.B.J.M. ten Berge \& R.J.G.M. Widdershoven, 2001, Bescherming Tegen de Overheid, Utrecht: W.E.J Tjeenk Willink Deventer, hal. 5. 
otentik. Dalam hal ini perlindungan hukum terhadap jabatan notaris telah diatur dalam ketentuan Pasal 66 ayat (1) UUJN-P, yang mengatur tentang lembaga MKN sebagai lembaga perlindungan hukum terhadap jabatan Notaris.

\subsection{Tujuan Penelitian}

Bertitik tolak dari rumusan permasalah diatas adapun tujuan dari penelitian ini secara umum adalah untuk menemukan jawaban atas permasalahan yang ada tersebut.

\subsubsection{Tujuan Umum}

Secara umum, penelitian ini bertujuan untuk pengembangan ilmu hukum dalam bidang hukum kenotariatan mengenai pemahaman terhadap standar atau syarat bagi seorang Notaris dalam melaksanakan jabatannya dalam pembuatan akta yang bersifat notariil dan perlindungan hukum terhadap Notaris berkaitan dengan adanya dugaan malpraktek yang dilakukan dalam proses pemuatan akta otentik.

\subsubsection{Tujuan Khusus}

Dalam penelitian ini, selain untuk mencapai tujuan umum di atas, terdapat juga tujuan khusus. Adapun tujuan khusus yang ingin dicapai sesuai dengan permasalahan yang dibahas dalam penelitian ini, yaitu :

1.4.2.2 Untuk menganalisis dan mengevaluasi standar atau syarat bagi seorang Notaris dalam melaksanakan jabatannya dalam pembuatan akta yang bersifat notariil.

1.4.2.3 Untuk menganalisis dan mengevaluasi perlindungan hukum terhadap Notaris berkaitan dengan adanya dugaan malpraktek dalam proses pembuatan akta otentik berdasarkan Undang-Undang Jabatan Notaris.

\section{METODE PENELITIAN}

\subsection{Jenis penelitian}

Jenis penelitian yang digunakan adalah penelitian hukum normatif. Penelitian hukum normatif tersebut dilakukan dengan meneliti bahan pustaka atau bahan sekunder seperti peraturan perundang-undangan dibidang perlindungan hukum terhadap notaris, bukubuku dan artikel-artikel yang mempunyai korelasi dan relevansi dengan permasalahan yang akan diteliti, serta teori-teori hukum dan pendapat para sarjana.

Dalam hal ini dilakukan penelitian terhadap Undang-Undang Nomor 2 Tahun 2014 Tentang Perubahan Atas Undang-Undang Nomor 30 Tahun 2004 Tentang Jabatan Notaris. Penelitian tersebut dilakukan berangkat dari adanya suatu kekaburan norma, karena tidak diatur secara tegas mengenai prosedur perlindungan hukum yang diberikan kepada Notaris melalui Majelis Kehormatan Notaris di dalam melakukan pemeriksaan terhadap notaris sebelum memberikan persetujuan kepada penyidik yang hendak memanggil Notaris dalam persidangan.

\subsection{Jenis Pendekatan}

Dalam penulisan penelitian tesis ini, jenis pendekatan yang digunakan adalah pendekatan perundang-undangan (statute approach), pendekatan konsep (conceptual approach) dan pendekatan perbandingan (comparative approach). Pendekatan perundang-undangan (statute approach) dilakukan untuk meneliti aturan-aturan hukum yang menjadi fokus penelitian, ${ }^{7}$ khususnya mengenai perlindungan hukum terhadap Notaris di dalam UndangUndang Jabatan Notaris. Pendekatan konsep (conceptual approach) dilakukan dengan mengidentifikasi dan memahami segala konsepkonsep hukum yang ditemukan dalam doktrindoktrin maupun pandangan-pandangan para sarjana. ${ }^{8}$ Sedangkan pendekatan perbandingan (comparative approach) dilakukan untuk melihat perbandingan antara satu aturan hukum yang mengatur ketentuan yang sama, namun tidak searah dengan hukum yang lainnya, sehingga dapat diketahui baik persamaan maupun perbedaan yang akan sangat membantu dalam proses analisis. ${ }^{9}$ Dalam hal ini digunakan perbandingan antara Undang-Undang Nomor 30 Tahun 2004 Tentang Jabatan Notaris, pasca terbitnya Putusan Mahkamah Konstitusi Nomor 49/PUU-X/2012 dan setelah berlakunya UU No 2 Tahun 2014 Tentang Perubahan Atas UU No 30 Tahun 2004 Tentang Jabatan Notaris.

\subsection{Sumber Bahan Hukum}

Sumber bahan hukum yang digunakan dalam penelitian ini dibagi menjadi bahan hukum primer dan bahan hukum sekunder :

1) Bahan-bahan hukum primer yang mengikat berupa norma dasar Pancasila, Kitab Undang-undang Hukum Perdata, Undang-Undang Nomor 2 Tahun 2014 Tentang Perubahan atas Undang-Undang Nomor 30 Tahun 2004 Tentang Jabatan Notaris, Putusan Mahkamah Konstitusi Nomor 49/PUU-X/2012, Kode Etik Notaris.

2) Bahan-bahan hukum sekunder yaitu bahan-bahan yang erat hubungannya dengan bahan hukum primer yang berupa bukubuku, karya tulis hukum atau pandangan ahli hukum yang termuat dalam media masa, internet dengan menyebut nama

${ }^{7}$ Johni Ibrahim, Teori \& Metodologi Penelitian Hukum Normatif, cet III, Bayumedia Publishing, Malang, hal 302.

${ }^{8}$ Peter Mahmud Marzuki, 2005, Penelitian Hukum, Kencana, Jakarta, hal. 139.

${ }^{9}$ Ibid, hal. 133. 


$$
\begin{aligned}
& \text { situsnya, serta artikel-artikel } \\
& \text { yang relevan dengan topik } \\
& \text { penelitian. }
\end{aligned}
$$

\subsection{Teknik Pengumpulan Bahan}

Hukum

Penelitian ini bersifat library research yang pengumpulan bahan hukumnya dilakukan dengan teknik dokumentasi, yaitu dikumpulkan dari telaah peraturan perundang-undangan, putusan Mahkamah Konstitusi, studi pustaka seperti, buku-buku, makalah, artikel, majalah, jurnal, koran, atau karya tulis para pakar. Selain itu, wawancara juga merupakan salah satu dari teknik pengumpulan bahan hukum yang menunjang teknik dokumentasi dalam penelitian ini serta berfungsi untuk memperoleh bahan hukum yang mendukung penelitian jika diperlukan.

Pengumpulan bahan hukum juga dilakukan dengan menggunakan sistem kartu (card system). Dalam pengumpulan bahan hukum tersebut, kartu-kartu disusun berdasarkan topik, bukan berdasarkan nama pengarang. Hal ini dilakukan agar memudahkan dalam hal penguraian, menganalisa dan membuat kesimpulan dari konsep-konsep yang ada. ${ }^{10}$

\subsection{Teknik Pengolahan Dan Analisis Bahan Hukum}

Untuk menganalisis bahan-bahan hukum yang telah terkumpul akan digunakan beberapa teknik analisis, seperti : teknik deskripsi, teknik argumentasi, dan teknik sistematisasi. Teknik deskripsi adalah teknik dasar analisis yang tidak dapat dihindari penggunaannya. Deskripsi berarti gambaran atau uraian apa adanya terhadap suatu kondisi atau posisi dari proposisi-proposisi hukum atau non hukum. Teknik argumentasi adalah memberi penilaian yang didasarkan pada alasan-alasan yang bersifat penalaran hukum. Teknik sistematisasi adalah upaya mencari kaitan rumusan suatu konsep hukum atau proposisi hukum antara peraturan perundang-undangan yang sederajat ataupun antara yang tidak sederajat.

\section{TINJAUAN PUSTAKA}

\subsection{Karakteristik Jabatan Notaris}

Pada abad ke II dan abad ke III sebelum masehi, bahkan jauh sebelumnya ada juga yang dinamakan notarii tidak lain adalah sebagai orang-orang yang memiliki keahlian untuk mempergunakan suatu bentuk tulisan cepat didalam menjalankan pekerjaan mereka. Para notarii ini memiliki kedudukan yang tinggi, bahwa pekerjaan mereka menuliskan segala sesuatu yang dibicarakan dalam pidato kaisar pada rapat-rapat yang membahas soal-soal rahasia kenegaraan.

${ }^{10}$ Winarno Surakhmad, 1972, Pengantar Penelitian Ilmiah, Dasar Metode \& Teknik, Tarsito, Bandung, hal. 257.
Selain para notarii, pada permulaan abad ke III sesudah masehi telah dikenal yang dinamakan tabeliones, mereka mempunyai beberapa persamaan dengan para notarius, karena mempunyai tugas demi kepentingan masyarakat umum untuk membuat akta-akta dan surat-surat lain, walaupun jabatan atau kedudukan mereka itu tidak mempunyai sifat kepegawaian dan juga tidak ditunjuk atau diangkat oleh kekuasaan umum untuk melakukan sesuatu formalitas yang ditentukan oleh Undang-Undang.

Lembaga Notaris masuk di Indonesia pada permulaan abad ke-17 bersamaan dengan hadirnya Vereenigde Oost Ind. Compagnie (VOC) di Indonesia. Tugas Notaris pada masa itu adalah untuk melayani keperluan para penduduk dan para pedagang serta melakukan semua surat libel (smaadschrift), surat wasiat di bawah tangan (codicil), akta perjanjian perdagangan, perjanjian kawin, surat wasiat (testament), dan akta-akta lainnya dan ketentuan-ketentuan yang perlu. ${ }^{11}$

Pada tahun 2004 diundangkanlah UndangUndang Nomor 30 Tahun 2004 Tentang Jabatan Notaris (UUJN) yang menjadi pedoman bagi institusi notaris di Indonesia, sampai akhirnya kini telah diamandemen oleh pemerintah Republik Indonesia menjadi Undang_Undang Nomor 2 Tahun 2014 Tentang Perubahan Atas Undang-Undang Nomor 30 Tahun 2004 Tentang Jabatan Notaris (UUJN-P). Merujuk pada ketentuan dalam Pasal 1 angka 1 UUJN-P yang menyatakan bahwa "Notaris adalah pejabat umum yang berwenang untuk membuat akta otentik dan memiliki kewenangan lainnya sebagaimana dimaksud dalam Undang-Undang ini atau berdasarkan Undang-Undang lainnya." Dapat diketahui bahwa, kewenangan Notaris selain diatur di dalam UUJN-P juga diatur dalam Undang-Undang yang lain, sepanjang kewenangan tersebut tidak diberikan kepada pejabat umum yang lainnya, maka kewenangan tersebut menjadi kewenangan Notaris. Prinsip seorang Notaris dalam menjalankan tugasnya haruslah memberikan pelayanan kepada semua pihak agar kepentingan semua pihak dapat terfasilitasi dalam akta otentik. Alhasil, Notaris dapat mencegah terjadinya suatu persoalan atau perselisihan di antara para pihak.

\subsection{Kode Etik Profesi Notaris}

Kode etik profesi adalah seperangkat kaedah, baik tertulis maupun tidak tertulis, yang berlaku bagi anggota organisasi profesi yang bersangkutan. Ikatan Notaris Indonesia (I.N.I) merupakan satu-satunya organisasi profesi yang diakui keberadaannya sesuai dengan Undang-

${ }^{11}$ Habib Adjie, 2008, Hukum Notaris Indonesia (Tafsir Tematik Terhadap UU No. 30 tahun 2004 Tentang Jabatan Notaris), Refika Aditama, Bandung, (selanjutnya disingkat Habib Adjie I), hal. 3. 
Undang Jabatan Notaris sesuai dengan Pasal 83 ayat 1 UUJN. Notaris, yang menjalankan profesi, wajib tunduk pada suatu peraturan yang bersifat internal yang berlaku dalam suatu organisasi profesi tertentu.Selain itu, Kode Etik Notaris juga berperan penting sebagai sarana kontrol sosial. ${ }^{12}$

Dalam menjalankan jabatannya seorang Notaris tidak pernah lepas dari kewajiban yang harus dipenuhi serta untuk memaksimalkan kinerjanya. Adapun kewajiban seorang Notaris sebagaimana yang disebut dalam Pasal 16 UUJN-P, yaitu bahwa seorang Notaris harus bertindak jujur,seksama, mandiri, tidak berpihak, dan menjaga kepentingan pihak yang terkait dalam perbuatan hukum. Selain itu seorang Notaris juga wajib membuat akta dalam bentuk minuta akta dan menyimpannya sebagai bagian dari protokol Notaris.

Dewan Kehormatan merupakan organ perlengkapan I.N.I yang terdiri dari anggotaanggota yang dipilih dari anggota I.N.I dan werda Notaris, yang berdedikasi tinggi dan loyal terhadap perkumpulan, berkepribadian baik, arif dan bijaksana, sehingga dapat menjadi panutan bagi anggota dan diangkat oleh kongres untuk masa jabatan yang sama dengan masa jabatan kepengurusan. Dewan Kehormatan berwenang melakukan pemeriksaan atas pelanggaran terhadap kode etik dan menjatuhkan sanksi kepada pelanggarnya sesuai dengan kewenangannya dan bertugas untuk:

1) melakukan bimbingan, pembinaan, pembenahan anggota dalam menjunjung tinggi kode etik;

2) memeriksa dan mengambil keputusan atas dugaan pelanggaran ketentuan kode etik yang bersifat internal atau yang tidak mempunyai masyarakat secara Iangsung;

3) memberikan saran dan pendapat kepada majelis pengawas atas dugaan pelanggaran kode etik dan jabatan Notaris.

Pelaksanaan sanksi yang dijatuhkan oleh Dewan Kehormatan Ikatan Notaris Indonesia sebagai organisasi profesi terhadap Notaris yang melanggar kode etik sebagaimana yang disebutkan dalam Pasal 6 Kode Etik Notaris dapat berupa teguran, peringatan, schorzing dari keanggotaan perkumpulan, onzetting (pemecatan) dari keanggotaan perkumpulan, pemberhentian secara tidak hormat dari keangotaan perkumpulan.

\subsection{Pengawasan dan Pembinaan Terhadap Notaris Dalam Menjalankan Tugas Jabatannya}

${ }^{12}$ Abdulkadir Muhammad, 2006, Etika Profesi Hukum, Bandung, Citra Aditya Bakti, hal.56

\subsubsection{Pengawasan terhadap Notaris}

Dalam Pasal 67 ayat (1) UUJN-P menentukan bahwa pengawasan terhadap Notaris dilakukan oleh Menteri. Dalam melaksanakan pengawasan tersebut Menteri membentuk Majelis Pengawas yang terdiri dari 9 (sembilan) orang, yang terdiri dari unsur Pemerintah sebanyak 3 (tiga) orang, organisasi Notaris sebanyak 3 (tiga) orang dan ahli/akademik sebanyak 3 (tiga) orang. Berdasarkan Pasal 68 UUJN, bahwa Majelis Pengawas terdiri dari Majelis Pengawas Daerah (MPD), Majelis Pengawas Wilayah (MPW), dan Majelis Pengawas Pusat (MPP).

MPD, dibentuk dan berkedudukan di kabupaten atau kota (Pasal 69 ayat 1 UUJN-P), MPW dibentuk dan berkedudukan di ibukota Propinsi (Pasal 72 ayat (1) UUJN), sedangkan MPP dibentuk dan berkududkan di ibukota Negara (Pasal 76 ayat (1) UUJN).Adanya unsur praktisi (Notaris) di dalam Majelis Pengawas merupakan bentuk dari adanya pengawasan secara internal, artinya dilakukan oleh sesama Notaris yang memahami dunia Notaris luardalam. Unsur lainnya merupakan unsur eksternal yang mewakili dunia akademik, pemerintah, dan masyarakat. Perpaduan dari anggota majelis pengawas ini yang diharapkan dapat memberikan sinergi pengawasan dan pemeriksaan yang objektif, sehingga setiap pengawasan dilakukan berdasarkan aturan hukum yang berlaku, dan para Notaris dalam menjalankan tugas jabatannya tidak menyimpang dari UUJN karena diawasi secara internal dan eksternal.

3.3.2 Keberadaan
Kehormatan Notaris $\begin{array}{r}\text { Majelis } \\ \text { sebagai }\end{array}$
isnstitusi yang melakukan
pembinaan terhadap Notaris

Sejak diundangkannya Undang-Undang Nomor 2 Tahun 2014 Tentang Perubahan Atas Undang-Undang Nomor 30 Tahun 2004 Tentang Jabatan Notaris (UUJN-P), telah dibentuk lembaga perlindungan hukum baru yang bernama Majelis Kehormatan Notaris (MKN) yang bertugas melaksanakan pembinaan, bimbingan, pengawasan dan pembenahan anggota dalam rangka memperkuat institusi Notaris dalam menjalankan amanah Undang-undang jabatan Notaris. Hal ini dapat dilihat dari maksud atau tujuan dibentuknya MKN sebagai suatu lembaga perlindungan hukum terhadap jabatan Notaris.

Keberadaan (MKN) ini diatur dalam Pasal 66 A ayat (1) UUJN-P yang menyatakan bahwa, dalam melaksanakan pembinaan, Menteri membentuk Majelis Kehormatan Notaris. Anggota dari Majelis Kehormatan Notaris (MKN) ini berjumlah 7 (tujuh) orang, yang terdiri atas unsur Notaris sebanyak 3 (tiga) orang; Pemerintah sebanyak 2 (dua) orang; Ahli atau akademisi sebanyak 2 (dua) orang. Peran 
penting dari lembaga MKN ini adalah "menggantikan" peran Majelis Pengawas Daerah (MPD) dalam menyetujui atau menolak pemanggilan Notaris dan pengambilan fotokopi protokol Notaris oleh penyidik, penuntut umum dan hakim. Majelis Kehormatan Notaris (MKN) ini merupakan badan yang bersifat independen dalam mengambil keputusan yang mempunyai tugas dan kewajiban untuk memberikan bimbingan atau pembinaan dalam rangka memperkuat institusi Notaris dalam menegakkan Undang-Undang Jabatan Notaris bagi setiap orang yang menjalankan jabatan sebagai Notaris.

\subsection{Malpraktek Notaris}

Istilah malpraktek sering digunakan oleh kalangan profesi untuk menggambarkan suatu kelalaian, kesalahan, penyimpangan atau bahkan ketidakmampuan yang dilakukan dalam menjalankan tugas profesi sehingga dapat merugikan konsumen atau klien. Penggunaan istilah malpraktek dapat terjadi pada profesi di bidang kesehatan (kedokteran), akuntan, ekonomi, hukum, teknik. Kini istilah malpraktek sudah semakin meluas dalam berbagai bidang disiplin ilmu, termasuk dalam bidang kenotariatan.

Penyimpangan terhadap tugas jabatan Notaris karena kelalaiannya dapat digolongkan ke dalam perbuatan malpraktek, baik dalam lingkup malpraktek karena melanggar etika profesi Notaris (ethical malpractice) maupun melanggar hukum kenotarisan (legal malpractice). Jadi, apabila ada pihak yang dirugikan oleh Notaris, terkait dengan akta yang dibuat oleh Notaris, pihak tersebut cukup melaporkan kepada Majelis Pengawas Notaris atau Dewan Kehormatan Notaris, jika kerugian itu timbul karena adanya pelanggaran dalam jabatan Notaris atau pelanggaran kode etik. Apabila perbuatan Notaris tersebut tergolong suatu perbuatan pidana dalam merumuskan akta otentik, maka para pihak dapat melaporkan tindakan Notaris tersebut ke polisi.

\section{STANDAR BAGI SEORANG NOTARIS DALAM \\ MELAKSANAKAN \\ JABATANNYA \\ DALAM \\ PEMBUATAN AKTA YANG BERSIFAT NOTARIIL}

4.1 Standar Bentuk dan Fungsi Akta Notaris

Akta Notaris wajib dibuat dalam bentuk yang sudah ditentukan oleh Undang-Undang. Hal ini merupakan salah satu karakter dari akta Notaris. Akta Notaris wajib mengandung unsur subyektif dan objektif dalam memformulasikan kehendak para pihak ke dalam suatu akta otentik. Oleh karena itu, dalam merumuskan suatu akta Notaris harus memperhatikan bentuk atau kerangka dari suatu akta Notaris, yang sebagaimana termuat dalam Pasal 38 UUJN-P, yaitu setiap akta Notaris terdiri atas Awal akta atau kepala akta, badan akta, dan akhir atau penutup akta.

Dalam awal akta atau kepala akta, harus memuat judul akta, nomor akta, waktu kapan akta tersebut dibuat, serta nama lengkap dan tempat kedudukan Notaris. Dalam badan Akta wajib memuat tentang identitas dari para penghadap, dan/atau orang yang mereka wakili, dan keterangan mengenai kedudukan bertindak penghadap. akhir atau penutup akta harus memuat mengenai pembacaan akta sebagaimana dimaksud dalam Pasal 16 ayat (1) huruf (m) atau Pasal 16 ayat (7), uraian tentang penandatanganan dan tempat penandatanganan atau penerjemahan akta jika ada serta identitas dari tiap-tiap saksi akta.

Akta mempunyai fungsi formil (formalitas causa) dan fungsi sebagai alat bukti (probationis causa). ${ }^{13}$ Akta sebagai fungsi formil artinya bahwa suatu perbuatan hukum akan menjadi lebih lengkap apabila dibuat suatu akta. Sebagai contoh perbuatan hukum yang harus dituangkan dalam bentuk akta sebagai syarat formil adalah perbuatan hukum disebutkan dalam Pasal 1767 KUHPerdata mengenai perjanjian hutang piutang. Fungsi akta lainnya yaitu sebagai alat pembuktian. Dibuatnya akta oleh para pihak yang terikat dalam suatu perjanjian ditujukan untuk pembuktian di kemudian hari.

\subsection{Standar Bagi Notaris Dalam Membuat Akta Yang Bersifat Notariil}

Dalam pembuatan suatu akta otentik seorang Notaris harus memperhatikan 3 (tiga) unsur penting didalamnya, sebagaimana yang dikemukakan oleh Dr. Ida Bagus Agung Putra Santika, S.H., M.Kn yaitu : ${ }^{14}$

1. Syarat sahnya suatu perjanjian (Pasal 1320 KUHPerdata)

2. Syarat dari suatu akta otentik (Pasal 1868 KUHPerdata)

3. UUJN+Kode Etik Notaris

Bahwa dalam pembuatan akta otentik hal pertama yang wajib dipenuhi adalah syarat sahnya suatu perjanjian sebagaimana yang diatur dalam Pasal 1320 KUHPerdata yang terdiri dari kesepakatan antara para pihak yang membuat perjanjian, adanya kecakapan bagi pihak yang mengadakan perjanjian, adanya suatu hal tertentu, dan adanya suatu sebab yang halal.

Unsur yang kedua yang wajib dipenuhi dalam pembuatan akta yang bersifat notariil yaitu harus mengandung syarat pembuatan akta otentik yang diatur dalam Pasal 1868 KUHPerdata yaitu:

\footnotetext{
${ }^{13}$ Sudikno Mertokusumo, 1993, Hukum Acara Perdata Indonesia, Edisi Keempat, Yogyakarta, Liberty, hal 115

${ }^{14}$ Wawancara, Ida Bagus Agung Putra Santika, SH., M.Kn, pada tanggal 2 Juli 2014
} 
- akta itu harus dibuat oleh (door) atau di hadapan (ten overstaaan) seorang Pejabat Umum.

- akta itu harus dibuat dalam bentuk yang ditentukan oleh undangundang

- Pejabat Umum oleh atau siapa akta itu dibuat, harus mempunyai wewenang untuk membuat akta tersebut. ${ }^{15}$

Unsur terakhir yang wajib dipenuhi dalam pembuatan akta otentik yaitu seorang Notaris harus selalu memperhatikan apa yang menjadi kewajiban atau kewenangannya sebagaimana yang diatur dalam UUJN serta dalam Kode Etik Notaris

\subsection{Sanksi Bagi Notaris Apabila Melanggar Standar Pembuatan Akta Otentik}

Peran Notaris hanyalah sebagai media untuk lahirnya suatu akta otentik, Notaris bukan pihak dalam akta yang dibuatnya, sehingga hak dan kewajiban hukum yang dilahirkan dari perbuatan hukum yang disebutkan dalam akta Notaris tersebut, hanya mengikat para pihak dalam akta itu. Jika terjadi sengketa mengenai isi perjanjian tersebut, maka Notaris tidak terlibat dalam pelaksanaan kewajiban untuk dituntut suatu hak, karena Notaris berada diluar perbuatan hukum pihak-pihak tersebut. Hal tersebut terjadi apabila Notaris telah bekerja atau menjalankan tugas jabatannya sesuai dengan undang-undang serta telah sesuai dengan kode etik Notaris.

Apabila Notaris bekerja tidak sesuai dengan standar profesinya atau melanggar ketentuan-ketentuan dalam proses pembuatan akta otentik, maka Notaris tersebut dapat dikenakan sanksi yang berupa sanksi administrasi, sanksi perdata dan sanksi pidana. Notaris dapat diberikan sanksi administrasi, apabila Notaris tersebut terbukti telah melanggar ketentuan-ketentuan etika profesinya yang telah diatur di dalam UUJN maupun dalam Kode etik Notaris. Sanksi administrasi dapat diberikan secara berjenjang, mulai dari teguran lisan, teguran tertulis, pemberhentian sementara, pemberhentian dengan hormat hingga pemberhentian tidak hormat sebagaimana yang diatur dalam Pasal 85 UUJN.

Sanksi perdata dapat diberikan kepada Notaris apabila pelanggaran yang dilakukan oleh Notaris sehingga mengakibatkan kerugian bagi para pihak atau salah satu pihak terkait dengan pelaksanaan akta Notaris tersebut, maka terhadap akta tersebut dapat diturunkan (didegradasi) kekuatan pembuktiannya menjadi akta dibawah tangan. Atas dasar tersebut, maka dapat menjadi alasan bagi para pihak yang

\footnotetext{
${ }^{15}$ Irawan Soerodjo, 2003, Kepastian
} Hukum Hak Atas Tanah Di Indonesia, Arkola, Surabaya, hal.148. menderita kerugian untuk menuntut penggantian biaya, ganti rugi dan bunga kepada Notaris. Selain sanksi administrasi dan sanksi perdata, apabila terjadi pelanggaran terhadap pembuatan akta otentik, Notaris juga dapat dikenakan sanksi pidana. Dalam praktek, banyak akta Notaris dipermasalahkan oleh para pihak atau pihak lainnya dan sering pula Notaris ditarik sebagai pihak yang turut serta melakukan atau membantu melakukan suatu tindak pidana terkait dengan akta yang dibuat oleh Notaris, misalnya, Notaris diduga telah melakukan pemalsuan surat atau Notaris dituduh telah memasukkan keterangan palsu ke dalam akta otentik (Pasal 264 KUHP).

\section{PERLINDUNGAN TERHADAP NOTARIS MELAKSANAKAN JABATANNYA}

\section{HUKUM JABATAN DALAM TUGAS}

\subsection{Perlindungan Terhadap Jabatan Notaris}

Notaris sebagai pejabat umum dalam membuat akta otentik harus selalu memperhatikan standar atau syarat-syarat dari suatu akta otentik, selain itu Notaris juga harus selalu berpijak pada aturan-aturan hukum yang berlaku (UUJN dan Kode Etik Notaris). Apabila semua syarat tersebut telah dipenuhi, maka Notaris tersebut dapat dipastikan bebas dari segala macam bentuk tuntutan yang diajukan kepadanya.

Undang-Undang Jabatan Notaris telah menempatkan Notaris sebagai pejabat umum, yang menjalankan tugas sebagai jabatan, karena itu perlu mendapatkan perlindungan hukum adalah Notaris sebagai jabatan, bukan Notaris sebagai pribadi. Perlindungan hukum atas hak Notaris merupakan hasil transformasi kepentingan yang dilakukan melalui proses legislasi dalam menjaga pembentuk hukum atau parlemen, sehingga hak Notaris dapat dihormati, atau dilindungi dan dipatuhi.

Undang-Undang Jabatan Notaris telah mengatur bentuk perlindungan hukum yang dapat diberikan kepada Notaris dalam menjalankan tugas jabatannya sebagai pejabat umum, hal ini tercermin dalam Pasal 66 ayat (1) UUJN-P yang menyatakan bahwa:

Untuk kepentingan proses peradilan, penyidik, penuntut umum, atau hakim dengan persetujuan Majelis Kehormatan Notaris berwenang:

a) mengambil fotokopi Minuta Akta dan/atau surat-surat yang dilekatkan pada Minuta Akta atau Protokol Notaris dalam penyimpanan Notaris; dan

b) memanggil Notaris untuk hadir dalam pemeriksaan yang 
berkaitan dengan Akta atau Protokol Notaris yang berada dalam penyimpanan Notaris.

Dalam pemahaman perlindungan hukum terhadap Notaris yang tercantum dalam Pasal 66 UUJN-P ini harus termasuk di dalamnya Notaris pengganti, Pejabat Sementara Notaris dan Notaris emeritus atau werda Notaris, karena dalam praktek masih sering dilakukan pemanggilan (pemeriksaan) kepada Notaris yang sudah berhenti menjabat sebagai Notaris untuk diperiksa oleh penyidik terkait dengan akta-akta yang pernah dibuatnya semasa masih menjabat sebagai Notaris. Diharapkan dengan adanya UUJN-P ini keberadaan Majelis Kehormatan Notaris dapat memberikan perlindungan hukum bagi semua orang yang (pernah) menjalankan tugas jabatan sebagai Notaris.

\subsection{Kecenderungan Notaris Dalam Menjalankan Tugas Jabatannya Diduga Melakukan Malpraktek}

Kedudukan seorang Notaris sebagai suatu fungsionaris dalam masyarakat hingga sekarang masih tetap disegani, untuk itu seorang Notaris sebagai pejabat umum dalam menjalankan tugasnya harus mampu memberikan pelayan yang maksimal kepada masyarakat, agar kepentingan semua pihak dapat terfasilitasi ke dalam suatu akta otentik. Dalam hal ini, Notaris harus mampu mencegah terjadinya suatu permasalahan yang muncul dikemudian hari melalui akta-akta yang dibuatnya, karena apabila salah satu pihak merasa dirugikan atau merasa tidak puas akan akta otentik yang dibuat oleh Notaris, maka tidak menutup kemungkinan Notaris tersebut akan dituntut atau digugat oleh pihak yang merasa dirugikan tersebut.

Pihak yang merasa dirugikan atas akta yang dibuat oleh Notaris, dapat menuntut Notaris tersebut secara pidana, karena banyak faktor yang dapat menjerat Notaris telah melakukan suatu tindak pidana terkait dengan pembuatan akta otentik, misalnya Notaris diduga telah membantu melakukan suatu tindak pidana dengan membuat surat palsu atau memasukkan keterangan palsu ke dalam akta otentik. Dalam hal ini Notaris harus berhati-hati dalam memformulasikan kehendak atau keinginan para pihak ke dalam suatu akta otentik, karena tidak menutup kemungkinan para pihak yang datang menghadap Notaris memiliki maksud yang tidak baik, yang justru memanfaatkan ketidakcermatan atau ketidaktilitian Notaris dalam memformulasikan kehendak para pihak. Walaupun Notaris telah bekerja sesuai dengan standar, namun masih saja ada kemungkinan bahwa ada pihak yang merasa tidak puas atau merasa dirugikan terkait dengan akta yang dibuat oleh Notaris tersebut. dan Notaris tersebut dapat diduga telah melakukan pelanggaran atau kesalahan (malpraktek) dalam pembuatan akta otentik.

\subsection{Prosedur Khusus Dalam Penegakan Hukum Terhadap Jabatan Notaris}

UUJN-P telah mengatur mengenai perlindungan hukum terhadap Jabatan Notaris yang dilakukan oleh Majelis Kehormatan Notaris (MKN), sebagaimana yang diatur dalam Pasal 66 ayat (1) UUJN-P, yang menyatakan bahwa untuk kepentingan prose peradilan, penyidik, penuntut umum maupun hakim, yang hendak memanggil Notaris harus mendapat persetujuan terlebih dahulu dari MKN. Apabila terjadi kasus terkait dengan adanya dugaan malpratek yang dilakukan oleh Notaris dalam proses pembuatan akta otentik yang menyebabkan kerugian bagi salah satu pihak dalam akta yang dibuatnya, maka dalam hal ini ada beberapa langkah-langkah yang harus dipatuhi bagi penyidik maupun MKN, guna menjamin kepastian dan perlindungan hukum bagi pihak-pihak yang terkait, yaitu :

1) penyidik, penuntut umum, maupun hakim untuk kepentingan proses peradilan dapat mengambil fotokopi Minuta Akta dan/atau surat-surat yang dilekatkan pada Minuta Akta atau protokol Notais dalam penyimpanan Notaris dengan mengajukan permohonan tertulis kepada Majelis Kehormatan Notaris (MKN), dan permohonan tersebut juga disampaikan kepada Notaris yang bersangkutan;

2) Majelis Kehormatan Notaris berwenang melakukan pemeriksaan terhadap Notaris yang dilaporkan telah melakukan tindak pidana dalam proses pembuatan akta.

3) Majelis Kehormatan Notaris dapat memberikan persetujuan kepada penyidik, penuntut umum maupun hakim apabila Notaris yang bersangkutan terbukti telah melakukan pelanggaran tindak pidana dalam proses pembuatan akta.

4) Apabila Majelis Kehormatan Notaris tidak menemukan adanya bukti pelanggaran terkait dengan adanya dugaan tindak pidana yang dilakukan oleh Notaris tersebut, maka dalam hal ini Majelis Kehormatan Notaris tidak dapat memberikan persetujuan bagi penyidik yang hendak memanggil Notaris tersebut.

5) Jangka waktu bagi Majelis Kehormatan Notaris dalam memberikan persetujuan atau tidak memberikan persetujuan secara tertulis kepada penyidik 
adalah 30 hari sejak diterimanya surat permohonan dari penyidik (Pasal 66 ayat (3) UUJN-P). Apabila dalam jangka waktu tersebut Majelis Kehormatan Notaris tidak memberikan jawaban, maka Majelis Kehormatan Notaris dianggap telah memberikan persetujuan (Pasal 66 ayat (4) UUJN-P).

MKN dalam kedudukan sebagai Badan atau Jabatan Tata Usaha Negara mempunyai kewenangan untuk membuat atau mengeluarkan Surat Keputusan atau Ketetapan yang berkaitan dengan hasil pemeriksaan yang ditujukan kepada Notaris yang bersangkutan. Keputusan MKN bersifat konkrit, Individual dan final.

Mengenai keberadaan MKN sebaiknya dibentuk di tingkat kabupaten atau kota (daerah), hal ini bertujuan untuk menghindari penumpukan perkara yang masuk dan harus diselesaikan melalui Majelis Kehormatan Notaris (MKN). Apabila lembaga pengawas ini ditempatkan di kabupaten atau kota, maka lembaga MKN dapat dengan cepat tanggap dapat memberikan keputusan untuk menyetujui atau menolak permintaan dari penyidik terkait dengan pengambilan fotokopi minuta akta atau pemanggilan notaris itu sendiri untuk kepentingan proses peradilan. Hal ini dikarenakan undang-undang hanya memberikan waktu 30 hari untuk memberikan putusan tersebut. Apabila tidak ada jawaban dalam rentang waktu itu, majelis kehormatan dianggap menyetujui permintaan tersebut.

Apabila dalam hal Majelis Kehormatan Notaris memberikan persetujuan bagi penyidik untuk memanggil Notaris untuk diperiksa, maka dalam hal ini Notaris tersebut dapat melakukan upaya hukum banding ke Pengadilan Tata Usaha Negara (PTUN). Hal tersebut dilakukan karena Majelis Kehormatan Notaris yang berkedudukan sebagai badan atau jabatan Tata Usaha Negara dan telah mengeluarkan keputusan sebagai suatu keputusan Tata Usaha Negara sebagai hasil akhir dari pemeriksaan. Terhadap tindakan Majelis Kehormatan Notaris yang memutuskan untuk menyetujui atau tidak menyetujui Notaris untuk diperiksa oleh pihak lain sebagai pelaksanaan Pasal 66 UUJN-P, maka dalam hal ini, Notaris atau penyidik yang merasa dirugikan terhadap keputusan MKN tersebut, dapat menempuh upaya hukum ke Pengadilan Tata Usaha Negara (PTUN).

Jadi berdasarkan uraian diatas, dengan adanya suatu prosedur khusus, serta ruang lingkup kewenangan yang jelas dari lembaga MKN, diharapkan MKN dapat memberikan suatu kejelasan dalam memberikan perlindungan hukum bagi institusi Notaris, dan dapat mempertegas keberadaan dari lembaga MKN tersebut. Hal ini juga bertujuan agar institusi Notaris tidak mudah disalahkan oleh pihak lain terkait dengan akta yang dibuat oleh Notaris.

\section{PENUTUP \\ 6.1 Simpulan}

Dari pembahasan yang telah diuraikan di atas, maka dapat diambil suatu simpulan, sebagai berikut :

1. Berdasarkan analisis mengenai standar yang harus dipenuhi Notaris dalam membuat akta otentik adalah harus memenuhi syarat-syarat sahnya perjanjian (Pasal 1320 KUHPerdata), syarat pembuatan akta otentik (Pasal 1868 KUH Perdata), serta harus tunduk pada ketentuan-ketentuan yang diatur dalam UUJN dan Kode Etik Notaris. Hal ini harus dilakukan, agar seorang Notaris mampu menghasilkan produk akta yang baik dan bebas dari permasalahan hukum.

2. Perlindungan hukum terhadap jabatan Notaris terkait dengan adanya dugaan malpraktek dalam proses pembuatan akta otentik telah diatur dalam Pasal 66 ayat (1) Undang-Undang Nomor 2 Tahun 2014 Tentang Perubahan Atas Undang-Undang Nomor 30 Tahun 2004 Tentang Jabatan Notaris yang mengatur keberadaan MKN sebagai lembaga perlindungan hukum terhadap jabatan Notaris. Keberadaan MKN ini pada dasarnya menggantikan peran dari MPD dalam memberikan persetujuan atau menolak permintaan penyidik yang hendak memanggil dan memeriksa Notaris dalam proses peradilan. Akan tetapi pengaturan mengenai kedudukan serta upaya hukum dari Majelis Kehormatan Notaris ini belum diatur secara tegas dalam suatu peraturan perundang-undangan.

\subsection{Saran-saran}

Dari hasil simpulan yang diuraikan diatas, dapat diberikan saran sebagai berikut :

1. Hendaknya Notaris dalam menjalankan kewenangannya membuat akta otentik harus selalu memperhatikan unsur-unsur atau syarat-syrat esensial dalam proses pembuatan akta otentik, agar Notaris dapat terhindar dari segala permasalahan hukum terkait dengan akta yang dibuatnya. Selain itu, juga agar dapat menjamin adanya perlindungan hukum bagi Notaris 
melalui lembaga Majelis

Kehormatan Notaris apabila nanti

Notaris tersebut diduga telah

melakukan pelanggaran atau

malpraktek dalam proses

pembuatan akta otentik.

2. Peraturan dalam Pasal 66 ayat (1) Undang-Undang Nomor 2 Tahun 2014 Tentang Perubahan Atas Undang-Undang Nomor 30 Tahun 2004 Tentang Jabatan Notaris hendaknya segera ditetapkan peraturan pelaksananya dalam suatu Peraturan Menteri maupun dalam Keputusan Menteri Hukum dan Hak Asasi Manusia, agar lebih jelas mengenai kedudukan serta fungsi dari Majelis Kehormatan Notaris itu sendiri.
Kedudukan lembaga Majelis Kehormatan Notaris ini seharusnya dibentuk tingkat kabupaten atau kota, agar lembaga dapat dengan cepat menanggapi dan memutuskan kasus yang terjadi. Selain itu pengaturan mengenai upaya hukum banding atas putusan Majelis Kehormatan Notaris perlu segera ditetapkan. Hal ini dilakukan untuk menjamin perlindungan hukum bagi Notaris dan sekaligus memberikan kesempatan untuk melakukan upaya banding bagi pihak-pihak yang merasa dirugikan atas putusan Majelis Kehormatan Notaris.

\section{DAFTAR PUSTAKA}

Abdulkadir Muhammad, 2006, Etika Profesi Hukum, Bandung, Citra Aditya Bakti

Habib Adjie, 2008, Hukum Notaris Indonesia (Tafsir Tematik Terhadap UU No. 30 tahun 2004

Hans Kelsen, 1944, General Theory Of Law And State, New York

Irawan Soerodjo, 2003, Kepastian Hukum Hak Atas Tanah Di Indonesia, Arkola, Surabaya

J.B.J.M. ten Berge \& R.J.G.M. Widdershoven, 2001, Bescherming Tegen de Overheid, Utrecht: W.E.J Tjeenk Willink Deventer

Jimly Asshiddiqie dan M. Ali Safa'at, 2006, Teori Hans Kelsen Tentang Hukum, Sekretariat Jendral \& Kepaniteraan Mahkamah Konstitusi Republik Indonesia, Jakarta

Johni Ibrahim, Teori \& Metodologi Penelitian Hukum Normatif, cet III, Bayumedia Publishing, Malang

Phillipus M. Hadjon, 1987, Perlindungan Hukum Bagi Rakyat Indonesia, PT. Bina Ilmu, Surabaya, (selanjutnya disebut Philipus M. Hadjon II)

M. Hadjon, 1997, Penataan Hukum Administrasi, Tentang Wewenang, Fakultas Hukum Unair, Surabaya, (selanjutnya disebut Philipus M. Hadjon I)

Peter Mahmud Marzuki, 2005, Penelitian Hukum, Kencana, Jakarta

Purbacaraka, 2010, Perihal Kaedah Hukum, Citra Aditya, Bandung

Sudikno Mertokusumo, 1993, Hukum Acara Perdata Indonesia, Edisi Keempat, Yogyakarta, Liberty

Winarno Surakhmad, 1972, Pengantar Penelitian Ilmiah, Dasar Metode \& Teknik, Tarsito, Bandung

Tentang Jabatan Notaris), Refika Aditama, Bandung, (selanjutnya disingkat Habib Adjie I) 